\title{
Indoor Navigation with Visible Light Communication using Genetic Algorithm
}

\author{
Emre Gözüaçık ${ }^{1 *}$, Mustafa Altık ${ }^{2}$, Levent Gökrem ${ }^{3}$ \\ ${ }^{1}$ Tokat Gaziosmanpaşa Üniversitesi, Mühendislik ve Mimarlık Fakültesi, Mekatronik Mühendisliği Bölümü, Tokat, Türkiye (ORCID: 0000-0003-2807-8187) \\ 2 Tokat Gaziosmanpaşa Üniversitesi, Mühendislik ve Mimarlık Fakültesi, Bilgisayar Mühendisliği Bölümü, Tokat, Türkiye (ORCID: 0000-0000-0000-0000) \\ ${ }^{3}$ Tokat Gaziosmanpaşa Üniversitesi, Mühendislik ve Mimarlık Fakültesi, Mekatronik Mühendisliği Bölümü, Tokat, Türkiye (ORCID: 0000-0003-2101-5378)
}

(International Congress on Human-Computer Interaction, Optimization and Robotic Applications (HORA) 2021 - 11-13 June 2021)

(DOI: $10.31590 /$ ejosat.952155)

ATIF/REFERENCE: Gözüaçık, E., Altıok, M. \& Gökrem, L. (2021). Indoor Navigation with Visible Light Communication using Genetic Algorithm. European Journal of Science and Technology, (26), 185-190.

\begin{abstract}
Today, people prefer supermarkets where they can meet all their needs today for their daily needs. People prefer large markets where they can meet all their needs today for their daily needs. These markets, which have a lot of product capacity, mean more waste of time for the consumer. In such indoor and large areas, it is necessary to plan a route to prevent loss of time. In this study, location determination process was made with visible light communication (VLC) in closed areas and the most suitable route was determined by using Genetic Algorithm (GA) with these locations. It is thought that wireless communication resources will not be sufficient in the future due to the density. VLC systems, developed to solve this problem, are a communication system that uses the light source for data transmission. It has been seen in related studies that this system is quite successful in terms of speed, reliability and energy efficiency. VLC systems basically use a transmitter, receiver and microcontroller for their control. In this study, LED light source, TEMP6000 phototransistor-light sensor and ATMEGA328P (Arduino) are used. Due to its very fast on and off feature, the data sent from the LED light source, is detected by the light sensor TEMP6000. After that, it was modulated using On-Off Keying (OOK). In addition to data transmission, VLC systems, which can be used to determine location especially in indoor areas, can also be used for indoor navigation. Also in this study, indoor positioning is designed on the basis of a market application with VLC. The location data was obtained according to the signal strength, which was transferred from the receiver to Matlab. The operation of the system has been tested on the basis of light sources, products under these sources and the shortest path to the products selected by the user. The shortest distance between the stops selected for this navigation process was found by the Floyd-Warshall algorithm. The shortest path was determined by using a GA for the stops with known distance between them, as in the Traveling Salesman Problem (TSP). In this way, the customer will be able to minimize the time and energy consumed in the market.
\end{abstract}

Keywords: Visible Light Communication (VLC), Indoor Positioning Systems (IPS), Traveling Salesman Problem, Genetic Algorithm (GA).

\section{Genetik Algoritma Kullanarak Görünür Işık Haberleşmesiyle İç Mekân Navigasyonu}

Öz

İnsanlar günlük ihtiyaçları için günümüzde her türlü ihtiyacını karşılayabileceği büyük marketleri tercih etmektedir. Çok fazla ürün kapasitesine sahip bu marketler, tüketici için gereğinden fazla zaman kaybı anlamına gelmektedir. Bunun gibi kapalı ve büyük alanlarda zaman kaybını önlemek için bir rota planlaması gerekmektedir. Bu çalışmada da kapalı alanlarda görünür 1şık haberleşmesi (VLC) ile konum belirleme işlemi yapılmış ve bu konumlar üzerinden genetik algoritma kullanılarak en uygun güzergah belirlenmiştir. Kablosuz haberleşme kaynaklarının yoğunluktan dolayı gelecekte yeterli olmayacağı düşünülmektedir. Buna çözüm amacıyla geliştirilen VLC sistemleri, ışık kaynağını veri iletimi için kullanan bir haberleşme sistemidir. Bu sistemin hız, güvenilirlik, enerji verimliliği gibi

${ }^{*}$ Corresponding Author: Tokat Üniversitesi, Mühendislik ve Mimarlık Fakültesi, Mekatronik Mühendisliği Bölümü, Tokat, Türkiye, ORCID: 00000003-2807-8187, emre.gozuacik@gop.edu.tr 
açılardan oldukça başarılı olduğu ilgili araştırmalarda görülmüştür. VLC sistemlerinde temel olarak verici, alıcı ve bunların kontorlü için bir mikrodenetleyici kullanılmaktadır. Bu çalışmada LED 1şık kaynağı, TEMP6000 fototransistör-1şık sensörü ve ATMEGA328P (Arduino) kullanılmıştır. Çok hızlı açılıp kapanma özelliği sayesinde LED ışık kaynağından gönderilen veri, 1şık sensörü TEMP6000 ile algılanmaktadır. Ardından Aç-Kapa Anahtarlama (OOK) kullanılarak modüle edilmiştir. Veri iletiminin yanısıra özellikle kapalı alanlarda konum belirlemek amacıyla kullanılabilen VLC sistemleri iç mekan navigasyonu için de kullanılabilmektedir. Bu çalışmada da, bir market uygulaması temelinde VLC ile kapalı alan konumlandırılması tasarlanmıştır. Alıcıdan alınan veriler Matlab üzerine aktarılmış sinyal gücüne göre konum verisi elde edilmiştir. Sistemin çalışması 1şık kaynakları, bu kaynaklar altındaki ürünler ve kullanıcının seçeceği ürünlere giden en kısa yol temelinde denenmiştir. Bu navigasyon işlemi için seçilmiş duraklar arasındaki en kısa mesafe Floyd-Warshall algoritması ile bulunmuştur. Aralarındaki mesafe bilinen duraklar için Gezgin Satıcı Problemi'nde olduğu gibi genetik algoritma kullanılarak en kısa güzergah belirlenmiştir. Bu sayede müşteri markette geçireceği zamanı ve tüketeceği enejiyi minimuma indirebilecektir.

Anahtar Kelimeler: Görünür Işık Haberleşmesi, Kapalı Alanda Konumlandırma Sistemleri, Gezgin Satıcı Problemi, Genetik Algoritma.

\section{Introduction}

Today, with the increasing use of wireless communication systems, radio frequency (RF) bands are filling up rapidly. This increase is expected to limit the use of wireless communication systems in the future. Therefore, alternative communication systems are being developed. One of these systems is VLC that transmit data through light. VLC systems have been developed as an alternative to wireless communication tools such as Wi-fi, bluetooth, zigbee, and RF. Due to the light visible to the human eye so it has taken the name of visible light communication and having an electromagnetic spectrum wavelength between 375 780 nm (Gözüaçık \& Gökrem, 2020).

Light emitting diodes such as LED and laser are used as transmitters in VLC systems (Ghassemlooy et al, 2017). Thanks to LED light sources, VLC systems are becoming more usable. Ensuring the flow of data by switching the light source on and off very quickly, highlights the importance of the light source. Since LED sources have an on-off speed of more than $20 \mathrm{MHz}$, can produce light in different colors and are cheap light sources, they are suitable for the use of VLC systems. In these systems, besides semiconductors such as phototransistor and photodiode, cameras can also be used as receivers (Luo et al, 2017; Ertuna, 2016). In addition, the receiver source have a higher operating frequency from the light source because it is necessary to detect the on-off information of light.

The suitability of a light source for VLC systems depends on the flicker specified in IEEE 802.15.7 standards to be faster than $200 \mathrm{~Hz}(<5 \mathrm{~ms})$. Although the speed of the data transmitted meets this, the ' 1 ' and ' 0 ' data that can come in succession may create a flicker effect. In this case, human health may be adversely affected. Data encoding methods (RLL, Manchester Code, etc.) are used to prevent flicker effect (Khan, 2017; Ghassemlooy et al, 2017). In order to detect the data generated by data coding methods, the modulation of the signal is provided by using carrier signals. Due to the modulation methods (OOK, Pulse Modulation, Ofdm, Color Shift-CSK modulation, etc.), the transmission and perception of data is easier (Ertürk, 2019; Uzun, 2019).

Methods that can be used with other communication systems to determine location in indoor, can often be used for VLC systems (Gözüaçık \& Gökrem, 2020). These methods (RSS, ToA, TDoA, AoA) give the position relationship between the receiver and the transmitter according to the recieved signal strength, signal arrival time, signal arrival time difference for more than one transmitter and signal arrival angle, respectively (Doughangi, 2017).

Location determination in indoor is used with wireless communication systems. Infsoft Company (2016) explained in its electronic book that the location determination process can be used in many areas such as airports, shopping malls, stations, hotels and factories. In addition, the features of systems used for these operations such as GPS, Wi-fi, bluetooth and VLC are given. The company has classified VLC systems according to where they are used. The advantages of light sources such as being suitable and widespread for buildings, energy saving, not disturbing or excessive cost of modern LED sources have been explained. In addition, disadvantages such as inflexible transmitter placement, special application requirement of the use of telephones as a receiver, and extra cost for buildings which light sources are stated.

Jerome et al. (2014), conducted a navigation study with 12 light source experimental setups they designed for indoor spaces. 8 Bits of data were sent from each source. In this study, which they carried out with a single receiver, they received the starting position information and made the routing process.

Sharifi et al. (2016), designed a robot with automatic control in their study and performed the positioning process of this robot using VLC. The movement of the robot whose position is determined using the RSS method with LEDs that have different frequencies, is provided.

Lv et al. (2017), used two receivers in their experimental setup with three LEDs and placed one receiver closer to the light sources. It evaluated ToA, TdoA, AoA and RSS methods which are among the location determination methods in terms of accuracy, ease of use and cost. Although the AoA method gives more sensitive results, it was decided that the RSS method and TdoA method were more advantageous in terms of cost and ease of use. It was measured by the fingerprint method and compared the actual values. The result accuracy value has been developed from $10 \mathrm{~cm}$ to $4 \mathrm{~cm}$ with this study.

PHILIPS (2016), provides information about VLC and indoor position system with the electronic book published in 2016. In addition, it gives information about the market application and usage patterns of VLC systems with Carrefour (Lille / France) hypermarket example. Thanks to this application, it is stated that customers have advantages such as determining product location, directing them to opportunity products, easy shopping and saving time.

With the VLC system designed for the market, the traveling salesman problem arises. TSP aims to determine the shortest distance between neighboring points, nodes or stops, which has become a problem since the 1800's (Kaya, 2012). Various mathematical equations, optimization methods, artificial intelligence algorithms are used to solve this problem (Kaya, 2012; Altıo, 2016). One of these methods is GA.

The GA is a type of algorithm based on natural selection, which allows the best genes to move into the future and eliminates bad genes. It is frequently used in methods such as optimization, 
classification, selection. GA is performed for initial population, selection, crossover and mutation operators depending on the fitness function (Alt1ok, 2016; Okur \& Atlas, 2020). Since each generation is created from the most suitable individuals of the previous generation, the best inheritance is passed on to the last generation. Operators applied to generations vary to reach the best result quickly.

The operators used in the GA also have different methods among themselves. First of all, the encoding stage is related to the representation and coding of the gene or chromosomes. At this stage, methods such as binary, hexa, permutation, etc. encoding are used. Then random selections are made between populations by the selection operator which based on techniques such as roulette, tournament, boltzmann, etc. Selected genes now represent the parents ready to crossover. These parent chromosomes change their genes among themselves according to certain methods and new chromosomes are formed. After the crossing operation, the changes expected to preserve genetic diversity in future generations, are performed with the mutation operator. Although there are studies in which the mutation operator is not used, there are also algorithm studies whose success has been increased with the mutation rate. New generation chromosomes are controlled with fitness function (Katoch et al, 2021). The population created is returned to the system as the new population. Apart from these, some GA parameters directly affect the result quality. Among these parameters, crossover and mutation rates, represent the chromosome and gene ratio to be operated. The population size represents the number of chromosomes the population contains. Iteration refers to the number of generations that will be formed for natural selection (Hassanat et al, 2019).

Keskintürk et al. (2016) made an study regarding the duties and mapping out a route of aircraft belonging to the Turkish Air Force between 12 military base regions. In this study, parameters such as aircraft take-off times, landing times and waiting times are also evaluated. As a result, the aircraft that had to move between the bases were able to fulfill their duties in minimum cost and time with the GA.

Ellili et al. (2017) conducted a study on the use of GAs for the traveling salesman problem. Analyzes were added after the algorithm was created and ran on Matlab. The algorithm has been created so that commercial representatives can visit 24 cities in Tunisia depending on the shortest path.

Karayel et al. (2019) chose a reference area on the map and worked on creating the most appropriate route from the starting point to the target point. With a $\mathrm{C}$ \# based interface, it is designed to add delay and error input depending on system specific conditions. A time-dependent and distance-dependent optimization study was carried out between 47 stops and a comparison was observed according to the mutation rate.

\section{Material and Method}

\subsection{Visible Light Communication}

VLC systems simply consist of a receiver, transmitter and processors that control them, just like other wireless communication systems. Unlike other wireless communication systems, it transmits data as visible light, not electromagnetic waves. In this way, it is possible to communicate with the light source in the areas where the lighting process is performed. By means of transmitter connected to the pin, digital data is converted to light. Light sensors detect the light coming from the source and digital data is analyzed with the processor (Windlin, 2016).

The light source used in VLC systems must have a structure that can quickly turn on and off. LEDs with this feature become advantageous as light sources. $1 \mathrm{~W}$ Power LED was used as a transmitter, together with the IRFZ44N Mosfet circuit and a TEMP6000 Light Sensor-Phototransistor was used as a receiver. The 1W LED and TEMP6000 light sensor were controlled by Atmega328 (Arduino) (Gözüaçık \& Gökrem, 2020; Gökrem et al, 2019; Durgun \& Gökrem, 2020).

The data produced in the processor is transferred to digital pin as " 1 " and "0" binary code. These data are saved as 8-bit data. In order to perceive these data easily, start bit ' 0 ' has been added to the beginning of the data and stop bit ' 1 ' has been added to the end. The data becomes 20 Bit data by Manchester Coding to prevent flickering. Manchester coding helps to transfer data easily and without errors. At the same time, it eliminates the flickering effect that may occur in the light source (Khan, 2017). Basically, ' 0 ' bits in the data are changed to ' 10 ' and the ' 1 ' bits to ' 01 '. The final data is sent to the LED as a digital signal to be transferred. 8-bit data was created, start and stop bits were added and manchester coding was applied to create the data to be transferred ( Gözüaçık \& Gökrem, 2020).

Thanks to the TEMP6000 phototransistor, the light emitted by the LED, is detected and applied to the Arduino analog input. Analog value becomes digital data consisting of "1" and " 0 " again with OOK (On-Off Keying) modulation. OOK modulation is a simple modulation technique that facilitates the transmission of the signal in communication systems. The digital data obtained takes its original form with Manchester decoding. With the detection of the start and stop bits, the information to be transferred begins to be read. In this way, data transfer in VLC systems is ensured.

\subsection{Indoor Positioning and Navigation System}

Wireless communication systems are also used for indoor positioning system. Signal used for data transmission, can detect the positions of the transmitter and receiver by methods such as arrival speed, arrivel time or angle of arrival. In VLC systems, this signal is represented by light. Data transferred by the light source, is sent to Matlab to be used in determining location. Thanks to these data, the distance of the receiver under the LED to the transmitter is determined by RSS method. The RSS method, as used in other communication systems, is a method used for location determination and depends on signal strength. It has been observed that it has high power values near the center and decreases circularly towards the outside. 

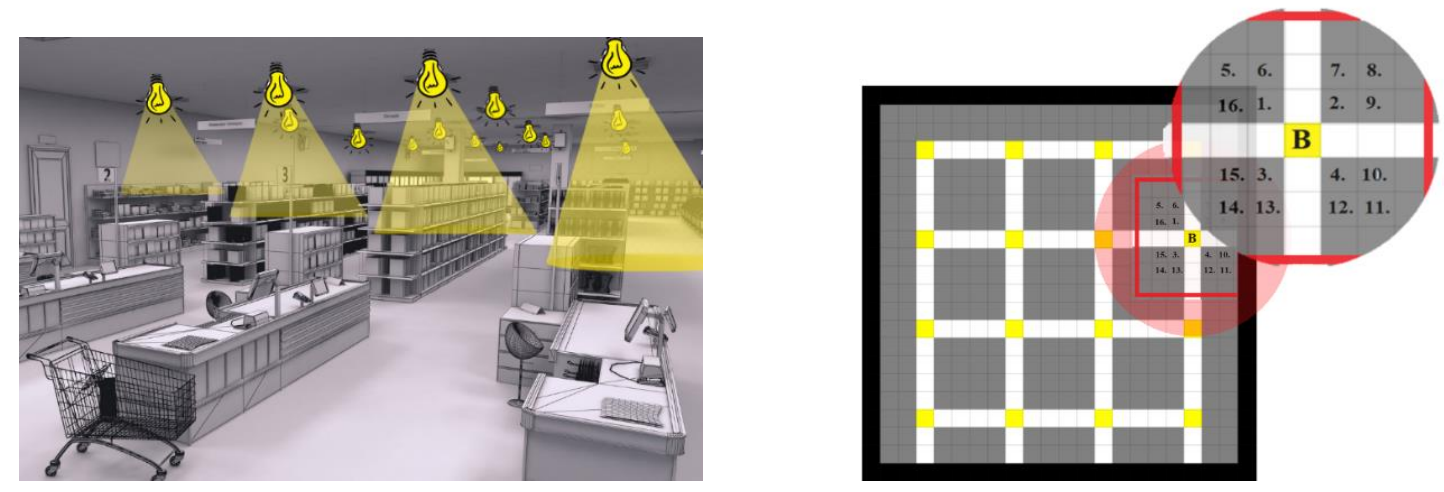

Figure 1. a) Market Light Sources, b) Matlab Demonstration

As a shown in Figure 1, to show that VLC systems can be used in daily life, an environment where light sources are placed, has been created on Matlab. This indoor area is considered as an example of a market. With this example, the position of the receiver under light sources and a selected route can be determined. Since the position of the the transmitters, i.e. light sources, will be fixed, the difference in distance between them has been determined. The shortest distance between two light sources was determined by the Floyd-Warshall algorithm and to map out a route. In this way, the user learns the shortest path from his current location to the desired location through light sources ( Gözüaçık \& Gökrem, 2020).

\subsection{Travelling Salesman Problem and Genetic Algorithm}

In this study, LED light sources represent the point, node or stop of the TSP. In the simulation made on Matlab, the distances between the light sources were determined. Then, the shortest distance between two points was determined using the FloydWarshall algorithm. The problem becomes more difficult as the number of nodes that have to visit between the starting and destination points increases. Genetic algorithm has been used to solve this problem.
First of all, permutation encoding is used to create populations and chromosomes. Permutation encoding is widely used in sequencing operations in an array, in TSP, and in work scheduling. It is simply that each point or node have a number value and these values make up the chromosome (Okur \& Atlas, 2020; Hassanat 2019). Thanks to the Roulette Method, a roulette wheel is created from random numbers based on their cumulative sum. Based on this wheel and crossover rate, the parent chromosomes were chosen. This parent chromosomes are crossed each other according to the before and after of a random point. Then, depending on the mutation rate, two randomly selected genes were replaced between themselves and swap mutation operation was performed. It was observed that as the number of nodes increased, the processing speed increased and more unsuccessful results were obtained. Hassanat et al. (2016), compared several mutation operators in their study and observed that using of more than one mutation, increased the success of the algorithm. Therefore, in this study, the algorithm has been developed by using flip, swap and slide mutation operators together. Gene change of crossover and mutation operators, are shown in Figure 2 (Wang et al, 2018).

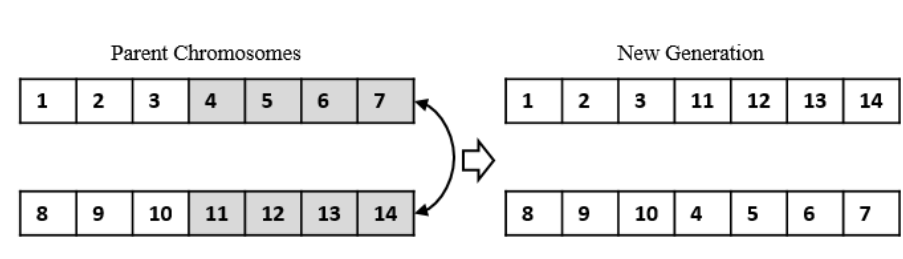

Crossover Operator

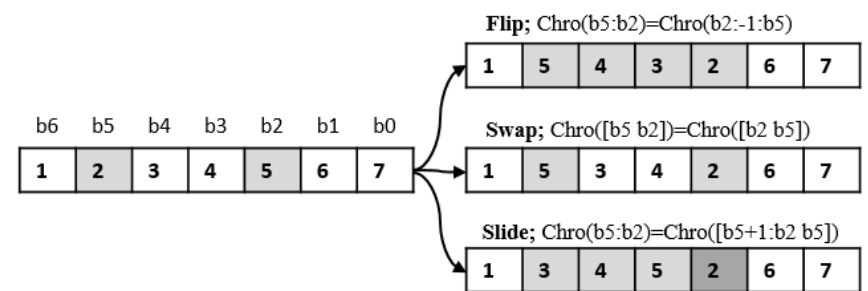

Mutation Operators

\section{Figure 2. Crossover and Mutation Operators for GA}

\section{Results and Discussion}

The experiments of this study were carried out with 1 W LEDs and TEMP6000 light sensor. Then measurements were made for RSS values. For a $15 \mathrm{~cm}$ high LED, the view of angle is approximately 60 degrees. Accordingly, in Equation (1), the RSS function was created by comparing the measured values and actual values. Thanks to this function, the horizontal distance of the receiver to the transmitter was measured with the RSS value (Gözüaçık \& Gökrem, 2020).
LED placement and product labels around the LED for Matlab simulation are shown in Figure 1. 16 light source representations (this number can be increased or decreased) were added in the display. The shelves around the light sources are shown with the product labels they contain (Gözüaçık \& Gökrem, 2020). Experimentally, a scenario like this has been realized; 1 the customer selects the desired products, 2- determines which light source the selected product labels are under, 3- the shortest distances between the target nodes, 4- the shortest path covering all nodes. Initially, this study was tested with a single mutation operator. When fewer nodes are preferred, the success rate reaches $100 \%$. On routes with a high number of nodes, the processing speed has decreased considerably and the accuracy rate has fallen 
below $86 \%$. Multiple mutation operators have been used to reduce high processing speed and error rate. Then, Flip, swap and slide operators are used. In addition, thanks to these processes, more hereditary features are tested and new generations are created more quickly. As a result, full success has been achieved in this simulation.

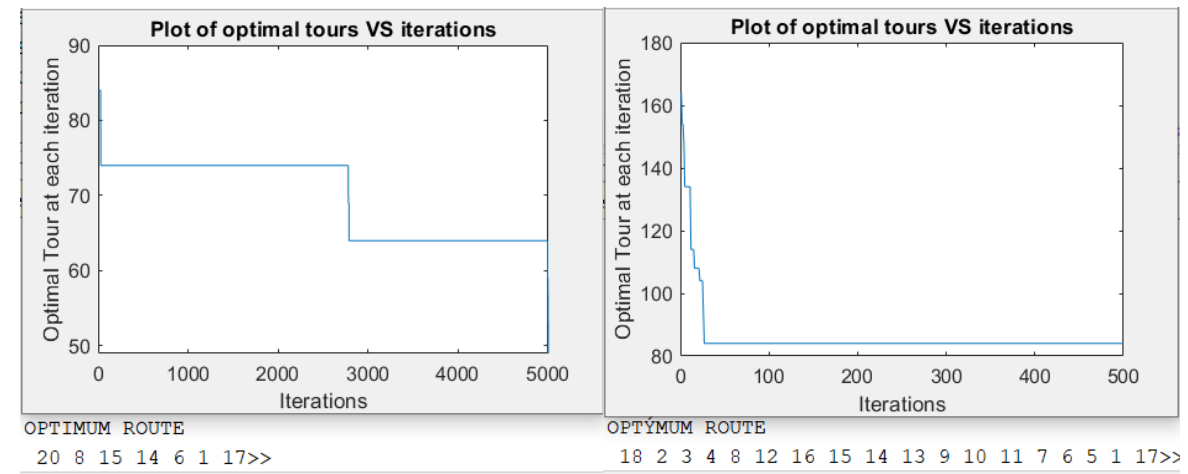

Figure 3. Optimal Route and Graph of Best Distance (left-one mutation, right-multi mutation)

In Figure 3, optimum routes graphs are shown according to interation size. Exchange of the results by the number of mutation operators, were seen in theese graphs.

\section{Conclusions and Recommendations}

In this study, VLC systems and IPS systems are used in common. Data transfer was carried out wirelessly with VLC systems. The location of the receiver has been determined thanks to the light sources. The shortest distance between two light sources has been found. In samples with more than one light source, the shortest route was created thanks to GA. Selection, crossover, mutation operators and their uses are shown in this study. Information was given about the effect of mutation operators on the results. This system, which will allow the movements in closed areas to be completed in a shorter time, is explained with the market example. Thanks to this study, a user will be able to make a shopping in the market in a short time.

Our research offers a solution to a real-life problem. In order to realize the simulation and demo version, there is a need for a closed area with a lighting system compatible with VLC systems. In addition, the front camera of smartphones should be used as a receiver instead of a light sensor so that the user can use it comfortably. Hardware and software developments are required for these cameras and phones. It is estimated that it can be easily done with a phone application.

The methods described in this study, can be used in many other areas. In particular, an example of a market is given as a closed area. However, any indoor areas which have a light source, where people are can be viewed as some form of VLC infrastructure. These studies can be increased with examples such as museums, theaters, cinemas, work offices, personal homes, etc.

\section{References}

Altıok, M. (2016). Çöp Konteynerlerinden Atık Toplama İşleminde Metasezgisel Yöntemler Kullanılarak Optimum Güzergâh Tespiti [Determination Of The Optimal Route Using Meta-Heuristic Methods Of Garbage Containers İn Garbage Collection Process], Master of Science, The Graduate School of Natural and Applied Science of Selçuk University, Department of Computer Engineering, Konya
Doughangi, H., (2017). Kapalı Alanda Konum Belirleme [Indoor Positionig System], Master of Science, İstanbul Commerce University, Graduate School of Applied and Natural Sciences Department of Computer Engineering, İstanbul-Turkey.

Durgun, M. \& Gökrem, L. (2020). VLC4WoT : Visible Light Communication for Web of Things, KSII Transactions on Internet and Information Systems, 14(4), 1502-1519.DOI: 10.3837/tiis.2020.04.006

Ellili, W., Samet, M. \& Kachouri, A. (2017). Traveling Salesman Problem of Optimization based on Genetic Algorithms, International Conference on Smart, Monitored and Controlled Cities (SM2C), 123-127.

Ertuna, A. D., (2016). Görünür Işık Haberleşme Sistem Tasarımı [Visible Light Communications and System Design], Master of Science, Yildiz Technical University Institute of Science, Department of Control and Automation Engineering, İstanbul-Turkey

Ertürk, S., (2019), Sayısal Haberleşme [Digital Communications], Birsen Publishing, Tokat-Turkey.

Ghassemlooy, Z., Alves, L. N., Zvanovec, S. \& Khalighi, M.-A., (2017). Visible Light Communications Theory and Applications, Taylor and Francis Group, Boca Raton.

Gökrem, L., Durgun, M. \& Durgun, Y. (2019). Indoor Location Control with Visible Light Communication, IEEE International Conference on Advanced Information and Communications Technologies (AICT), 314-316, doi: 10.1109/AIACT.2019.8847765.

Gözüaçık, E. \& Gökrem, L. (2020). Görünür Iş1kla Haberleşme ile Konum Belirleme [Visible Light Communication with Indoor Positioning], Journal of New Results in Engineering and Natural Sciences , $11,23-35$.

Hassanat A., Alkafaween E, Alnawaiseh N., Abbadi M., Alkasassbeh M. \& Alhasanat M.B. (2016). Enhancing genetic algorithms using multi mutations. PeerJ Preprints 4:e2187v1 https://doi.org/10.7287/peerj.preprints.2187v1

Hassanat, A., Almohammadi, K., Alkafaween, E., Abunawas, E., Hammouri, A. \& Prasath, V. B. S. (2019). Choosing Mutation and Crossover Ratios for Genetic Algorithms-A Review with a New Dynamic Approach. Information, 10(12), 390. doi:10.3390/info10120390

Infsoft, (2016). Indoor Positioning and Navigation. Großmehring. 
Jerome, K., Tony, V. \& Dhanaraj, V. R., (2014). Indoor Navigation Using Visible Light Communication, Texas Instruments India Educators' Conference, 46-52.

Karayel, M., Çelik, E. \& Yücedağ, İ. (2019), Genetik Algoritma Tabanlı İki Nokta Arasında En Kısa Yol Bulma, III. International Scientific and Vocational Studies Congress, 376-385.

Katoch, S., Chauhan, S.S. \& Kumar (2021). A review on genetic algorithm: past, present, and future. Multimed Tools Applications, $\quad 80, \quad 8091-8126$. https://doi.org/10.1007/s11042-020-10139-6

Kaya, İ. (2012). Genetik Algortimaların Optimal Güzergah Belirlenmesine Uygulanmas1 [Optımal Genetıc Algortthms Determınıng the Implementation of Route], Master of Science, Haliç University Institute of Science, Department of Computer Engineering, İstanbul.

Keskintürk, T., Uz, E. \& Topal, M. (2016). Genetic Algorithm Approach for Capacitated and Distance Constrained Periodic Travelling Salesman Problem: Scheduling and Routing of Turkish Air Forces' A400M, Journal of Academic Approaches, 7(1), 53-68.

Military Transport Aircraft

Khan, L. U., (2017). Visible Light Communication: application, architecture, standardizationand research challenges, Digital Communications and Networks, 3, 78-88.

Luo, J., Fan, L. \& Li, H., (2017). Indoor Positioning Systems Based on Visible Light Communications: State of Art, IEEE Communications Surveys and Tutorials, 19(4), 2871- 2894.

Lv, H., Feng, L., Yang, A., Guo, P., Huang, H., \& Chen, S., (2017). High Accuracy VLC Indoor Positioning System With Differential Detection. IEEE Photonics Journal, 9(3), 1-13, doi: 10.1109/JPHOT.2017.2698240.

Okur, E. \& Atlas, M. (2020). Araç Rotalama Probleminin Genetik Algoritma ile Çözümü [Solution of Vehicle Routing Problem with Genetic Algorithm], Anadolu University Journal of Social Sciences, 20 (3), 227-254.

PHILIPS, (2016). Indoor Positioning White Paper, (2019, 4 September), https:// cdn. fs. agorize. com/ yYsIkB46SAegMUK3hnuz

Sharifi, H., Kumar, A., Alam, F., \& Arif, K. M., (2016). Indoor Localization of Mobile Robot with Visible Light Communication, 12th IEEE/ASME International Conference on Mechatronic and Embedded Systems and Applications (MESA) , 1-6, doi: 10.1109/MESA.2016.7587166

Uzun, P. (2019). Görünür Iş̧1k Haberleşmesinde Modülasyon Türlerinin Incelenmesi [Investigation of Modulation Types in Visible Light Communication], Master of Science, Tokat Gaziosmanpaşa University Institute of Science, Department of Mechatronics Engineering, Tokat.

Wang Z., Liu L., Long T. \& Wen Y., (2018). Multi-UAV Reconnaissance Task Allocation for Heterogeneous Targets Using an Opposition-Based Genetic Algorithm with DoubleChromosome Encoding, Chinese Journal of Aeronautics, 31(2): 339-350. DOI: 10.1016/j.cja.2017.09.005.

Windlin, C., (2016). Visible Light Communication as a Material for Design, KTH Royal Institute of Technology, Stockholm. 